\title{
二次元ノズルから静止気体中に噴出する水膜流の振動と崩壊
}

Oscillation and breakup of planar liquid sheet ejected into an ambient gas

○ 薩摩林真（信州大） 戸崎正道（信州大院）正 佐々木篤史（信州大）

\begin{abstract}
Shin SATSUMABAYASHI, Shinshu University, Wakasato4-17-1, Nagano, 380-8553
Masamichi TOSAKI, Shinshu University

Atsushi SASAKI, Shinshu University
\end{abstract}

Key Words: Liquid sheet, Growth rate, Wave number, Oscillation

1. はじめに

ノズルから気体中に噴出された液体噴流は, 噴流自身の不 安定性と気液界面での相互作用によって振動し, 液滴に分 裂する．静止気体中に噴出された二次元液体噴流の不安定 性について，不安定なモードは 5 つ存在することが線形安 定性理論から明らかにされ, 実験結果と比較されている(1). また，気液界面での相対速度を考虑した二次元液体噴流に ついても，線形安定性理論による解析結果が示されている (2). 一方で二次元液体噴流に関する実験的な研究は少なく， 擋乱の成長を測定する方法は確立されていない, そのため, 流速と振動振幅の増幅率との関係 ${ }^{(3)}$ は調べられているもの の, 擋乱の成長を系統的に測定できていない. 本研究では, 二次元ノズルから静止気体中に噴出する水膜流において, 摚乱の波数の違いによる成長率の変化を調べた. 水膜流に 周期的な圧力変動を与えることで流れの状態を制御し，振 動振幅および波面の傾斜角の増幅率を測定することで擋乱 の成長率を定量的に評価した。

\section{2. 実験装㽬および実験方法}

実験装置の概略を Fig.1 に示す. 幅 $1.0 \mathrm{~mm}$ ，スパン方向 長さ $50 \mathrm{~mm}$ の噴出口形状を持つノズルから静止気体中に水 膜流を噴出させた。 ノズル出口における平均流速 $U$ を 4.0 $\sim 8.2 \mathrm{~m} / \mathrm{s}$ の範囲で変化させ, 水膜流の振動状態と崩壊過程 を観察した。なお座標系はノズルの噴出口中心を原点とし， 流れ方向に $x$ 軸, 流れと直角な方向に $y$ 軸を考えることと する。

水膜流の振動状態は初期乱れの強さに大きく依存してい る. 水膜流の初期乱れを, 実験時に与える圧力変動よりも 小さくするため, 上流からの流れは開口比が $73 \%$ 金網と

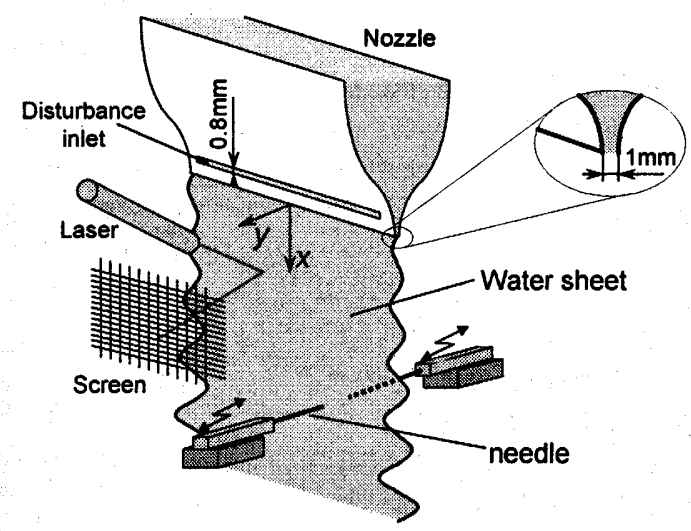

Fig.1 Schematic sketch of liquid sheet ejected from two dimensional nozzle.
絞り比が50のノズルによって整流されている.また,ノズ ルの表面は直径 $50 \mu \mathrm{m}$ のコンパウンド粒子を用いて研磨 されている.

水膜流に周期的な圧力変動を与えるため, 噴出口より $20 \mathrm{~mm}$ 上流の位置に, スパン方向に一様な幅 $0.8 \mathrm{~mm}$ の擋乱 挿入口を設けた. 擋乱挿入口には厚さ $0.3 \mathrm{~mm}$ の隔壁を介し て定格出力が $30 \mathrm{~W}$ のスピーカーが接続されており, 圧力変 動を与えることで振動を励起させた。この実験装置では, 励起周波数 $f$ を $50 \sim 500 \mathrm{~Hz}$ の範囲で変化させることができ る.

振幅 $A$ と波面の傾斜角 $\theta$ を測定し，それらの増幅率を求 めることで擋乱の成長率を評価した．位置分解能が $10 \mu \mathrm{m}$ の精密移動ステージに取り付けられたニードルが水膜流に 接触する位直を測定することで, 振幅 $A$ を求めた。 ニード ルの先端が水膜流の水面に接触すると通電するようこード ル部を陽極，金属性ノズルの表面を陰極とすることで，接 触状態を電気信号から判定できるよう工夫した。 また，水 膜流の水面にレーザー光を照射し，反射光の振れ幅の最大 值を照射点から $230 \mathrm{~mm}$ 離れたスクリーン上で測定するこ とによって波面の傾斜角 $\theta$ を求めた。

\section{3. 实験結果と考察}

ノズル出口における平均流速が $U=8.2 \mathrm{~m} / \mathrm{s}$ の条件におい $\tau, f=140 \mathrm{~Hz}$ の周期的な圧力変動を与え, 水膜流の振動を 撮影した. $450 \leqq x \leqq 980 \mathrm{~mm}$ の範囲における振動の様子を Fig.2 に示す. 水膜流は $y$ 方向に振動し, $x$ の増加に伴い振 幅は大きくなることがわかる。この振動はスパン方向にほ ぼ一様であり，流れ方向に波数を持っている．画像から波 長 $\lambda$ を測定した結果， $x \leqq 800 \mathrm{~mm}$ の範囲では，おおよそ $\lambda$ $=60 \mathrm{~mm}$ 程度であり，xの変化にかかわらずほぼ一定であっ た. また, これよりも下流の位置では水膜流が崩壊し, 液 滴が飛散する様子が観察された。

流れ方向の波数の違いによる擋乱の成長を評価するた めに, 励起周波数を $50 \leqq f \leqq 300 \mathrm{~Hz}$ の範囲で変化させ, $x=400 \mathrm{~mm}$ の位置で振幅 $A$ を測定した．波数 $a$ に対する振 幅 $A$ の変化を, ノズル出口での平均流速 $U$ の違いにわけ

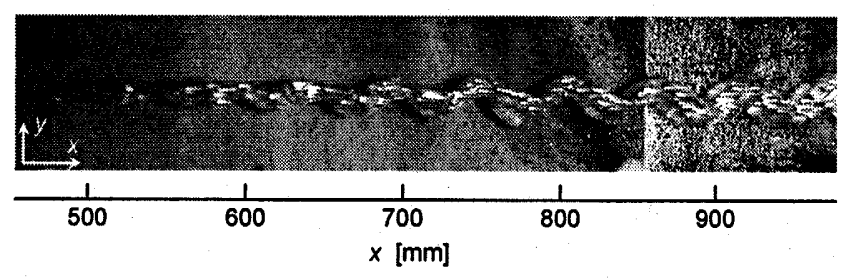

Fig.2 Oscillation and breakup of planar liquid sheet. $U=8.2 \mathrm{~m} / \mathrm{s}$. 
て Fig.3 に示す.ただし,ここに示す波数 $\alpha$ の值は, 励起 周波数 $f$ と平均流速 $U$ から求めている.

初期擋乱を与之ない場合, 水膜流の振幅 $A$ は $U=4 \mathrm{~m} / \mathrm{s}$ の 場合 $A=0.01 \mathrm{~mm}, U=8 \mathrm{~m} / \mathrm{s}$ の場合 $A=0.03 \mathrm{~mm}$ であった。これ に対し，初期擋乱を与えることによっていずれの波数 $\alpha$ で も振幅 $A$ は大きくなることがわかる.ただし，その值は波 数 $\alpha$ によって異なる. 波数 $\alpha$ の增加に伴い振幅 $A$ の值は大 きくなり $U=8 \mathrm{~m} / \mathrm{s}$ の場合 $\alpha=100 \mathrm{~m}^{-1}$ 程度, $U=4 \mathrm{~m} / \mathrm{s}$ の場合 $\alpha$ $=140 \mathrm{~m}^{-1}$ 程度で極大值をとる.このことから $U$ の増加に伴 い, 振幅が極大值をとる波数は減少することがわかる.ま た，Uが大きいほど振幅 $A$ の值は大きくなる．波数 $\alpha$ が大 きくなると，振幅 $A$ の值は小さくなり， $\alpha$ が $300 \mathrm{~m}^{-1}$ より も大きくなる範囲では初期擋乱を与えない場合の振幅值に 漸近する. 流速の違いによって振幅が成長しやすい摚乱の 波数が異なること, 平均流速 $U$ が大きいほど振幅が大きく なることは，気相および液相の粘性を考慮した線形安定性 解析の結果 ${ }^{(2)}$ と定性的に一致する。

波数 $\alpha$ の違いによる初期擋乱の成長率を定量的に評価す るため, $x$ の変化に対する振幅 $A$ および波面の傾斜角 $\theta$ を 測定し,それらの増幅率を求めた。 $U=8 \mathrm{~m} / \mathrm{s}$ における $x$ に対 寸る $A$ と $\theta$ の変化を, 波数 $\alpha$ の違いにわけて Fig.4に示す.

代表的な波数として, Fig.3の結果より振幅の変化が最も大 きい $\alpha=133 \mathrm{~m}^{-1}$ と最も小さくなる $\alpha=196 \mathrm{~m}^{-1}$ を選択した.

初期擋乱を与えない場合， $x$ の増加に対して振幅 $A$ と波 面の傾斜角 $\theta$ はどちらも指数関数で増加することがわかる. このことから，水膜流に与えた擋乱は線形成長していると 考えられる. 測定結果を指数関数で近似し， $A$ と $\theta$ の増幅 率 $\sigma$ をそれぞれ求めると, 両者はほぼ等しく, $\sigma=6.3 \times 10^{-3}$ 程度であった。一方, 初期摚乱を与えて振動を励起した場 合に注目すると， $A$ と $\theta$ の増幅率は波数 $\alpha$ によって異なる ことがわかる. $A$ の増幅率について，初期擋乱を与えない 場合と比較すると， $\alpha=133 \mathrm{~m}^{-1}$ の場合は $13 \%$ 程度高くなる のに対して, $\alpha=196 \mathrm{~m}^{-1}$ の場合は $5 \%$ 程度低くなる. 波数 $\alpha$ の違いによって擋乱の成長率は異なることが示された。

同様に, $U=4 \mathrm{~m} / \mathrm{s}$ における $x$ に対する $A$ と $\theta$ の変化を, $\alpha=141 \mathrm{~m}^{-1}$ と $\alpha=392 \mathrm{~m}^{-1}$ の場合にわけて Fig.5 に示す. ただ しこの条件では，下流の位置ほどノズル端部からの影響が

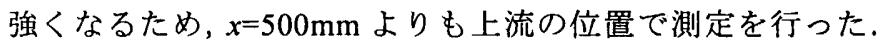
初期擋乱を与えない場合， $x$ の増加に対し $A, \theta$ とも指数 関数で増加することは $U=8 \mathrm{~m} / \mathrm{s}$ のときと同様である.次に， 流速の違いによる擋乱の成長率を評価する， $U=4 \mathrm{~m} / \mathrm{s}$ の条 件では振幅 $A$ の変化が非常に小さく, 測定される振幅 $A$ の 増幅率には計測誤差が含まれている，そのため，比較的誤 差が少ない波面の傾斜角 $\theta$ の増幅率を用いて擋乱の成長率 を評価する. $U=4 \mathrm{~m} / \mathrm{s}$ における $\alpha=141 \mathrm{~m}^{-1}$ での $\theta$ の増幅率は $U=8 \mathrm{~m} / \mathrm{s}$ における $\alpha=133 \mathrm{~m}^{-1}$ の $\theta$ の増幅率よりも $16 \%$ 減少し ている.また，初期擋乱を与えない場合と比較しても， $\theta$ の増幅率は $U=8 \mathrm{~m} / \mathrm{s}$ よりも $U=4 \mathrm{~m} / \mathrm{s}$ の方が $26 \%$ 减少してい る.このことから初期擋乱の有無によらず流速が低いほど 擋乱の成長率は低くなることがわかる.

\section{4.おわりに}

静止気体中に噴出する水膜流に周期的な圧力変動を与え ることで水膜流の振動を制御し，水膜流の振幅および波面 の傾斜角の増幅率を測定した. 水膜流に与えた初期擋乱は, 波数や平均流速の違いに関わらず線形成長することを明ら かにした。また，擋乱の成長率は波数に依存し，ノズル出 口における平均流速の違いによって成長率の高い波数が異 なることを示した.

\section{参考文献}

(1) L. Daniel Sorderberg, J. Fluid Mech. 493 (2003), 89-119.

(2) Guillermo Hauke et al, Flow Turbulent and Combustion, Vol.67 (2001) 235-265.

(3) Janewan Park et al, Phys. Fluids, 16 No.3, March (2004).

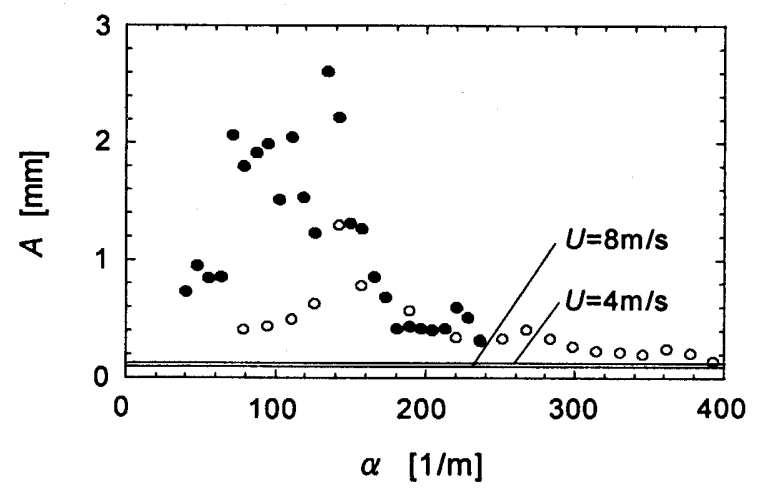

Fig.3 Oscillation amplitude against wave number of initial disturbance at voltage $E=9 \mathrm{~V} . \quad O: U=4 \mathrm{~m} / \mathrm{s}, \quad O: U=8 \mathrm{~m} / \mathrm{s}$, Solid line: without disturbance.

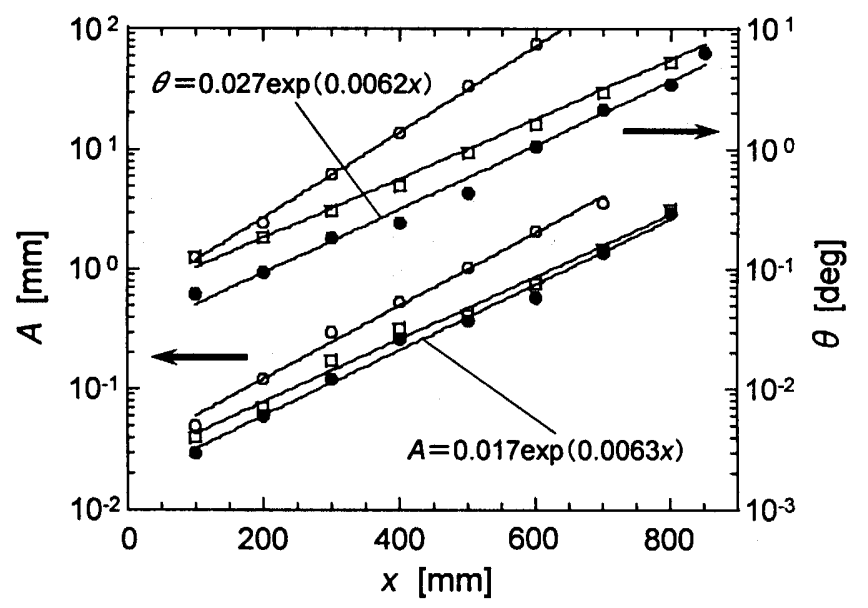

Fig.4 Comparison between oscillation amplitude and slope angle on growth rate in the case of $U=8 \mathrm{~m} / \mathrm{s}$. : without disturbance, $O: \alpha=133 \mathrm{~m}^{-1}, E=3.5 \mathrm{~V}, \square: \alpha=196 \mathrm{~m}^{-1}$, $E=3 \mathrm{~V}$.

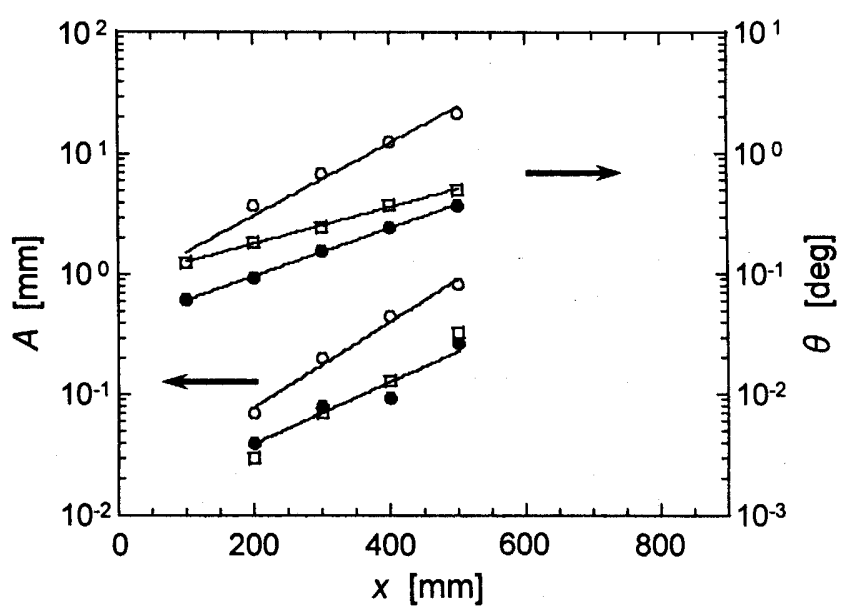

Fig.5 Comparison between oscillation amplitude and slope angle on growth rate in the case of $U=4 \mathrm{~m} / \mathrm{s}$. : without disturbance, $O: \alpha=141 \mathrm{~m}^{-1}, \quad E=2 \mathrm{~V}, \quad \square: \alpha=392 \mathrm{~m}^{-1}$, $E=1.5 \mathrm{~V}$. 